\title{
Kisspeptin neuronal networks in pubertal development of domestic female ruminants
}

\author{
Marcel Amstalden ${ }^{1}$ and Gary Williams ${ }^{1,2}$ \\ ${ }^{1}$ Department of Animal Science, Texas A\&M University, College Station, Texas, USA; 77845-2471; \\ ${ }^{2}$ Animal Reproduction Laboratory, Texas A\&M AgriLife Research, Beeville, Texas, USA; 78102-8571
}

\begin{abstract}
Summary
The pubertal activation of high-frequency episodic pulses of $\mathrm{GnRH}$ is believed to occur as a result of a change in the balance between inhibitory and excitatory stimuli to GnRH neurons. Kisspeptin neurons have been identified as major components of the pathway that regulates $\mathrm{GnRH}$ neuronal activity and appear to mediate the effects of estradiol in the control of $\mathrm{GnRH}$ secretion. The influence of nutrition on timing the onset of puberty may also involve kisspeptin neurons. Neuropeptide Y (NPY) and proopiomelanocortin (POMC) neurons in the hypothalamus interact with kisspeptin neurons in a network that is likely to mediate the nutritional and gonadal steroid regulation of reproductive function. Pre- and postnatal programming of these neuronal networks may be a primary mechanism by which nutrition and endocrine factors time the onset of a pubertal pattern of $\mathrm{GnRH}$ secretion. The genetic components underlying the function of these networks have begun to be revealed with the availability of highthroughput technologies and computational tools. A complex, highly interactive network of regulatory genes appears upstream to KISS1 and probably involves multiple cellular phenotypes. Characterization of the cellular location, temporal activation, and biological function of the various molecular components of the genetic network that regulate kisspeptin neuronal pathways will be essential for a full understanding of the role of KISS1 in the process of pubertal maturation.
\end{abstract}

\section{Introduction}

Age at first parturition has a great impact on lifetime productivity of food-producing mammals, including ruminants. Therefore, understanding the mechanisms that regulate the onset of puberty and the establishment of regular estrous cycles in domestic ruminant species is critical for optimizing reproductive efficiency in production systems. It is well established that the onset of regular ovulatory cycles follows the maturation of the reproductive neuroendocrine axis and the establishment of a pubertal pattern of episodic release of GnRH (Foster \& Jackson 2006). 
The pubertal activation of high-frequency pulsatile secretion of $\mathrm{GnRH}$ is believed to occur as a result of a decreased inhibition and increased excitation of $\mathrm{GnRH}$ neurons by afferent signals that act directly or indirectly to regulate $\mathrm{GnRH}$ release. Among these signals, kisspeptin has been demonstrated to be essential. In the past decade, a number of studies have supported the precept that kisspeptin is a potent stimulator of gonadotropin secretion in various species, including ruminants (Messager et al 2005, Kadokawa et al 2008). It also appears that kisspeptin neurons integrate endocrine and metabolic signals that mediate the nutritional control of reproductive neuroendocrine function (Castellano et al 2005). However, a more thorough understanding of the role of kisspeptin in the process of pubertal development is essential before kisspeptin, and kisspeptin receptor agonists and antagonists, can be utilized effectively in novel strategies to control the timing of the onset of puberty and improve reproductive efficiency. In this article, we present an overview of the involvement of kisspeptin neurons, and the associated neuronal network, on the control of GnRH secretion during pubertal development with emphasis in domestic female ruminants.

\section{Neuroendocrine control of the onset of puberty}

Puberty in females can be defined as the first ovulation followed by an estrous cycle of normal length for the species. Initiation of a high-frequency pattern of pulsatile release of $\mathrm{GnRH}$, and consequently $\mathrm{LH}$, is considered a critical neuroendocrine event for the support of final stages of follicular growth and maturation, elevated gonadal steroidogenesis and first ovulation (Foster \& Jackson 2006). In ruminants, first ovulation during pubertal transition is often followed by a short luteal phase (Berardinelli et al 1979). Although ovulation can be induced in prepubertal females by pharmacological treatments, a return to an anovulatory state is common if not accompanied by maturation of the neuroendocrine axis (Redmond et al 2011a).

The presence of the gonads is a major determining factor for maintenance of infrequent episodic release of $\mathrm{LH}$ during the prepubertal period. Ovariectomy leads to an increase in the frequency in LH release, and estradiol replacement maintains LH pulsatility similar to that of intact, prepubertal females (Day et al 1984, Ebling et al 1990). Therefore, estradiol is the major gonadal hormone maintaining the release of $\mathrm{LH}$ at a pattern typical of the prepubertal period.

\section{Role of estradiol positive and negative feedback}

Heightened sensitivity of the reproductive neuroendocrine axis to estradiol negative feedback maintains the pulsatile release of LH during the infantile and juvenile periods at a low frequency. As the female matures, the sensitivity to estradiol inhibition attenuates and the frequency of release of $\mathrm{LH}$ increases. This developmental change has been observed in ovariectomized, estradiol-replaced heifers and lambs exhibiting increases in the frequency of LH release concurrent with the increase in LH pulsatility observed in peripubertal, intact females (Day et al 1984, Ebling et al 1990). Therefore, a reduction in estradiol negative-feedback during pubertal transition plays a critical role in the maturation of the reproductive neuroendocrine axis. Enhanced gonadotropin stimulation leads to increased circulating concentrations of estradiol, which in turn, triggers a surge in $\mathrm{GnRH} / \mathrm{LH}$ release that causes ovulation. The mechanisms by which estradiol controls reproductive function include genomic and nongenomic actions involving the classical estrogen receptors ESR1 (alpha) and ESR2 (beta), the recently-characterized membrane receptor $G$ protein-coupled estrogen receptor 1 (formerly GPR30), and the putative membrane receptors mER-Gaq and ER-X (reviewed by Sinchak \& 
Wagner 2012). Studies in mice indicate that the actions of estradiol in the control of release of LH appear to be mediated primarily by ESR1 (Dorling et al 2003). Because GnRH neurons in sheep do not appear to contain ESR1 (Lehman \& Karsch 1993), estradiol regulation of episodic secretion of $\mathrm{GnRH}$ is likely mediated by estradiol-sensitive afferent pathways to $\mathrm{GnRH}$ neurons.

\section{Nutritional and metabolic control of pulsatile GnRH release}

The influence of nutrition on the reproductive development of domestic female ruminants is well established. Feed restriction during the juvenile period delays puberty (Foster \& Olster 1985, Day et al 1986) primarily by inhibiting the pulsatile release of GnRH (I'Anson et al 2000). In contrast, increased rate of body weight gain and adiposity during the juvenile period advances the onset of puberty (Gasser et al 2006). The interactive influence of nutrition and estradiol on timing pubertal onset is also evident. Inhibition of pulsatile secretion of LH by undernutrition is enhanced in ovariectomized ewe lambs treated with estradiol (Foster \& Olster 1985) and the early onset of puberty in heifers fed to gain body weight at high rates is associated with attenuation of estradiol negative feedback (Gasser et al 2006).

Hormones and metabolic factors have been implicated in signaling nutritional status to the central control of reproduction. Among these factors, leptin, an adipocyte-derived hormone, has generated great interest. Although early studies in mice and rats indicated that leptin was able to advance puberty, later studies in laboratory rodents and cattle demonstrated that leptin alone is insufficient to trigger puberty (Cheung et al 2001, Maciel et al 2004, Zieba et al 2004). Nevertheless, leptin is considered a necessary signal for normal pubertal development. The mechanism by which leptin exerts a permissive effect remains to be fully determined, but likely involves neurons located in the arcuate (ARC) nucleus (Satoh e al 1997) and possibly the premammillary region of the hypothalamus (Donato et al 2011). Neurons in these areas are proposed to relay leptin signals to the cellular network that controls $\mathrm{GnRH}$ neuronal function. Direct effects of leptin on GnRH neurons are unlikely because conditional deletion of functional leptin receptor gene in $\mathrm{GnRH}$ neurons does not impair reproduction in mice (Quennell et al 2009). Among the potential mediators of leptin action, neuropeptide Y (NPY) and proopiomelanocortin (POMC) neurons in the ARC are primary candidates. Kisspeptin neurons may also mediate the effects of leptin in the regulation of reproductive neuroendocrine functions.

\section{Kisspeptin neurons as mediators of the activation of $\mathrm{GnRH}$ secretion during pubertal development}

Kisspeptin as a GnRH secretagogue

A role for kisspeptin in the regulation of reproductive function was revealed with the report that mutations in the gene encoding kisspeptin receptor $(K I S S 1 R)$ was associated with disruption of normal pubertal development in humans and mice (de Roux et al. 2003, Seminara et al. 2003). Two populations of kisspeptin neurons are observed in the brain of mammals with neuronal cell bodies located in the preoptic (POA)/rostral periventricular (PeV) area and in the ARC nucleus (Franceschini et al. 2006, Smith et al. 2007, Ohkura et al 2009). These two populations are biochemically and functionally distinct (Goodman et al. 2007) and may have discrete roles in regulating $\mathrm{GnRH}$ secretion.

Kisspeptin is produced in various isoforms cleaved from a precursor peptide (Kotani et al 2001), but the decapeptide corresponding to the C-terminus has full biological activity. 
Kisspeptin is a potent stimulator of gonadotropin release (Messager et al 2005, Kadokawa et al 2008), an effect that appears to occur through stimulation of GnRH secretion (Messager et al 2005, Arreguin-Arevalo et al 2007). Direct effects of kisspeptin in GnRH neurons is supported by the observations that KISS1R is present in GnRH neurons (Smith et al 2011), kisspeptin projections are in close proximity to $\mathrm{GnRH}$ neurons (Smith et al 2008a), and kisspeptin increases firing potentials of GnRH neurons in tissue preparations (Han et al 2005).

The kisspeptin stimulation of GnRH release appears critical for pubertal activation of the reproductive neuroendocrine axis. Exogenous administration of kisspeptin advances the onset of puberty in rats (Navarro et al 2004) and mice (Han et al 2005), whereas treatment with a kisspeptin antagonist delays the onset of puberty (Pineda et al 2010). In prepubertal ewe lambs, intermittent injections of kisspeptin stimulated the episodic release of $\mathrm{LH}$, an effect that was associated with increased circulating concentrations of estradiol and ovulation/follicular luteinization (Redmond et al 2011a). The stimulatory effect of kisspeptin on gonadotropin secretion appears to be developmentally regulated because the kisspeptin-induced release of $\mathrm{GnRH}$ and $\mathrm{LH}$ increases with age (Castellano et al 2006). Developmental changes are also observed in kisspeptin innervation of GnRH neurons. As ewe lambs mature, the number of kisspeptin neuronal projections in close proximity to $\mathrm{GnRH}$ neurons increases (Nestor et al 2012). These morphological alterations may be essential for the role of kisspeptin in the pubertal activation of episodic release of $\mathrm{GnRH}$. Stimulation of gonadotropin release by direct effects of kisspeptin in the adenohypophysis is also possible (Smith et al., 2008b; Suzuki et al 2008); however, it is unclear whether it is physiologically relevant for the control of gonadotropin release (Arreguin-Arevalo et al 2007, Smith et al 2008b).

The absolute requirement of kisspeptin for normal reproductive function has been challenged by studies demonstrating that deletion of kisspeptin cells during fetal development does not impair pubertal development and fertility in mice (Mayer \& Boehm 2011). These studies have also demonstrated that when ablation of kisspeptin cells is performed postnatally, fertility is compromised. Although the ablation of kisspeptin neurons in the hypothalamus was not complete, these studies indicate the potential development of compensatory mechanisms that may overcome the absence of normal kisspeptin signaling in mice. Another possibility is that a small number of kisspeptin neurons is sufficient for sustaining GnRH secretory activity.

The functional distinction of the two kisspeptin neuronal populations is demonstrated by the heterogeneity in colocalization of various neuropeptides in kisspeptin neurons. Kisspeptin neurons located in the ARC nucleus colocalize neurokinin B and dynorphin (Goodman et al 2007, Wakabayashi et al 2010), but those located in the POA do not. Heterogeneity in kisspeptin afferent projections to brain areas and target cells is also observed between the populations of kisspeptin neurons (Yeo \& Herbison 2011). Physiologically, the relevance of this functional distinction is demonstrated by the response to local administration of kisspeptin. Kisspeptin injection in both the POA and ARC stimulates the release of LH in ovariectomized, estradiol-replaced rats, and the injection of kisspeptin antagonist into the ARC inhibits the pulsatile release of LH (Li et al 2009). However, this inhibitory effect is not observed when the kisspeptin antagonist is injected into the POA. Estradiol regulation of KISS1 expression is also distinct between the two populations of kisspeptin neurons (Smith et al 2005; Smith et al 2007) and the distinction appears to constitute the pathway by which estradiol controls the episodic and surge modes of GnRH secretion.

\section{Kisspeptin neurons as mediators of estradiol control of gonadotropin secretion}

Kisspeptin neurons express receptors for gonadal steroid hormones and are direct targets for estradiol. In mice (Smith et al 2005), rats (Takase et al 2009) and pigs (Tomikawa et al 
2010), estradiol increases KISS1 expression in the rostral periventricular region. In ewes, the number of KISS1 mRNA-containing cells in the POA/PeV increases during the late-follicular phase (Smith et al 2009), a time in which circulating concentrations of estradiol are expected to be elevated. The stimulatory actions of estradiol on KISS1 expression in the POA led to the hypothesis that estradiol positive feedback stimulation of the preovulatory surge of LH is mediated by activation of kisspeptin neurons in that region. In sheep, this notion is supported by studies indicating that kisspeptin neurons in the POA/PeV are activated (based on the presence of FOS immunoreactivity) during the preovulatory GnRH/LH surge (Hoffman et al 2011, Merkley et al 2012). However, discrepancies in the extent of the involvement of ARC kisspeptin neurons in the estradiol positive feedback exist. The studies by Merkley et al (2012) indicate that kisspeptin neurons in the ARC are also activated in response to estradiol positive feedback. In contrast, Hoffman et al (2011) did not detect FOS protein in kisspeptin neurons in the ARC at the time of the peak of the GnRH surge ( $26 \mathrm{~h}$ after estradiol implants were inserted). Methodological differences and timing of tissue collection in relation to the estradiol stimulation of the $\mathrm{GnRH} / \mathrm{LH}$ surge may have been sources of inconsistency between studies. Therefore, the extent of the involvement of kisspeptin neurons in the estradiol positive feedback remains to be fully elucidated.

There is greater consistency in support of a role for kisspeptin neurons in the ARC in mediating estradiol negative feedback. At low, basal concentrations, estradiol inhibits KISS1 expression (Smith et al 2007, Takase et al 2009). Estradiol withdrawal in ovariectomized, estradiol-replaced ewes is associated with an acute increase in the number of kisspeptin-immunoreactive cells in the ARC (Merkley et al 2012). In addition, saporin ablation of kisspeptin neurons in the ARC of rats markedly reduces the elevation in circulating concentrations of LH that follows ovariectomy (Mittelman-Smith et al 2012). Because the mediobasal hypothalamus has been demonstrated to be a major area for estradiol negative feedback regulation of gonadotropin secretion (Caraty et al 1998), the involvement of estrogen receptor-containing kisspeptin neurons in the ARC is a compelling pathway mediating estradiol inhibition of GnRH release.

Estradiol appears to have a major influence on the postnatal activation of kisspeptin synthesis. An increase in kisspeptin expression and immunoreactivity in the ARC is evident in rats from the early infantile period to adulthood (Takase et al 2009, Desroziers et al 2012). Such effects appear to require estradiol because kisspeptin immunoreactivity in the ARC is diminished in aromatase knockout mice (Clarkson et al 2009). In female sheep, kisspeptin immunoreactivity in the ARC is increased in postpubertal compared to prepubertal ewes (Nestor et al 2012). The activation of KISS1 expression during pubertal development has been demonstrated in various mammalian species including sheep (Redmond et al 2011a). Although increased KISS1 expression is observed in both POA/PeV and ARC populations, the timing of the activation of gene expression within each population appears distinct. In ovariectomized, estradiol-replaced ewe lambs, the number of cells containing KISS1 mRNA in the POA/PeV increases during the juvenile period; however, this increase is not associated directly with changes in the pattern of pulsatile LH release (Redmond et al 2011b). In contrast, the increase in the number of KISS1-expressing cells in the ARC is associated with increased frequency of LH release (Fig. 1). This observation indicates that the developmental decrease in sensitivity to estradiol negative feedback, and consequent increased frequency of LH release, is associated with activation of KISS 1 expression in the ARC. This hypothesis is supported by observations in the rat (Takase et al 2009). However, in contrast to ewe lambs, the increase in KISS1 expression during this period in female rats was observed in both POA/rostral PeV and ARC regions. The role of estradiol and ESR1 signaling in kisspeptin neurons was demonstrated in studies using conditional knockout of ESR1 in kisspeptin neurons (Mayer et al 2010). In that study, lack of ERS1 signaling 
A

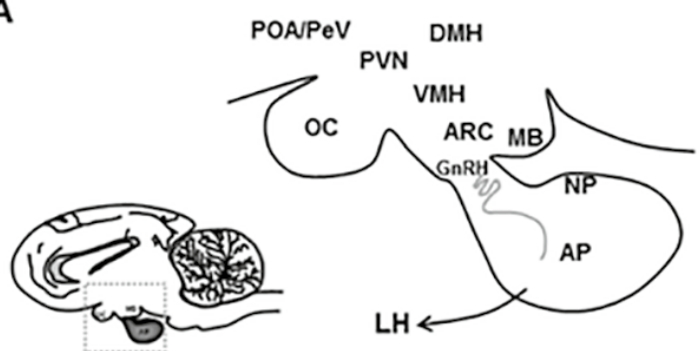

B
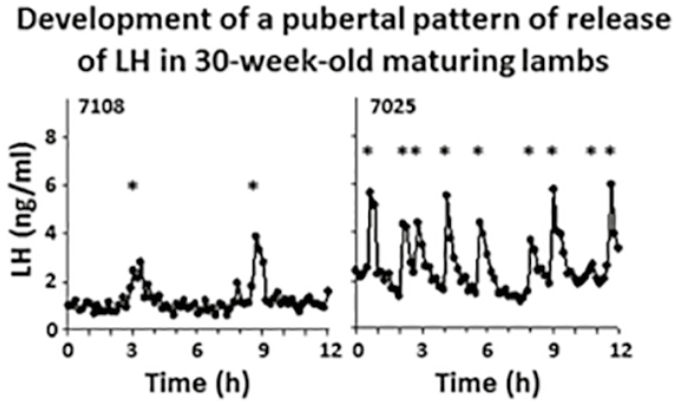

C

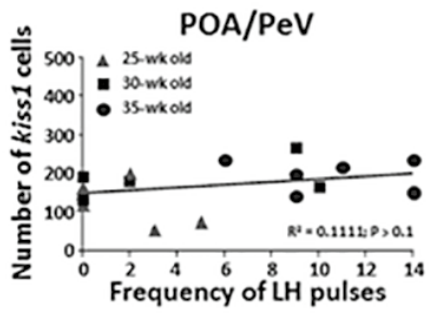

D

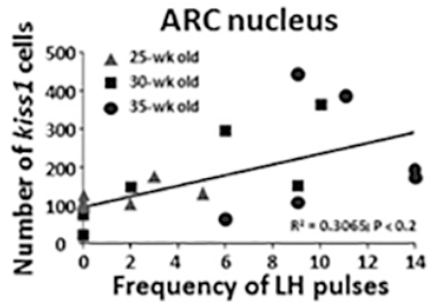

$\mathrm{E}$

ARC nucleus

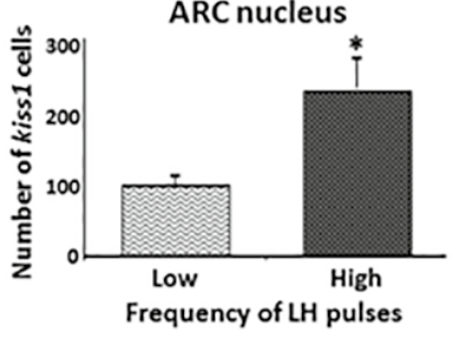

Fig. 1. Activation of KISS1 during pubertal development of a high-frequency, pulsatile release of LH in ewe lambs. A) Drawing representing the preoptic area (POA) and hypothalamus (boxed area at the base of the brain), and the location of various hypothalamic regions and their anatomical relationship with the adenohypophisis (AP) and neurohypophysis (NP; magnified drawing). KISS1 is expressed in the POA periventricular area $(\mathrm{PeV})$ and in the arcuate $(\mathrm{ARC})$ nucleus. Gonadotropin-releasing hormone $(\mathrm{GnRH})$ released in the hypothalamic-hypophyseal vasculature stimulates the release of $\mathrm{LH}$ from gonadotropes in the AP. B) Pattern of secretion of LH in ewe lambs at 30 weeks of age exhibiting low (left) and high (right) frequency of LH release. C, D) Regression analysis of the number of KISS1 mRNA-containing cells in the POA/PeV (C) and ARC (D) as a function of the frequency of LH pulses detected in developing ewe lambs. The number of KISS1 cells increase as the frequency of LH pulses increase in the ARC, but not in the POA/PeV. E) Number of KISS 1 cells in the ARC is greater in ewe lambs exhibiting a high frequency of $\mathrm{LH}$ release. (Modified from Redmond et al 2011b). DMH, dorsomedial hypothalamus; MB, mammillary body; OC, optic chiasm; PVN, paraventricular nucleus; VMH, ventromedial hypothalamus.

in kisspeptin neurons was associated with advanced puberty in mice. This observation supports the hypothesis that a reduction in estradiol negative feedback in kisspeptin neurons is critical for timing the onset of puberty.

Integrative role of kisspeptin neurons in hypothalamic pathways mediating the metabolic control of pubertal development

Nutritional and metabolic signals have been shown to regulate kisspeptin neuronal function. Inhibition of LH release by undernutrition is associated with decreased expression of KISS1 in 
rats (Castellano et al 2005). Kisspeptin administration in fasted rats restores the release of $\mathrm{LH}$ and alleviates the delay in pubertal onset (Castellano et al 2005). In addition, the observation that leptin increases KISS1 expression in lean, ovariectomized ewes (Backholer et al 2010) indicates that leptin's action in the regulation of reproductive neuroendocrine function may involve the kisspeptin pathway. However, the functional relevance of kisspeptin neurons as direct targets of leptin is unclear. Leptin receptor mRNA has been observed in kisspeptin neurons (Smith et al 2006, Backholer et al 2010), but kisspeptin neurons do not appear to be activated by leptin (Quennell et al 2011). In addition, targeted deletion of leptin receptor in kisspeptin neurons does not affect the onset of puberty or fertility in mice (Donato et al 2011). Therefore, intermediary pathways may integrate the metabolic regulation of kisspeptin neuronal activity.

Neuronal circuits encompassing NPY and POMC cells in the hypothalamus are considered major pathways by which nutritional signals control the reproductive neuroendocrine axis. These neurons are responsive to changes in nutritional status, an effect that involves leptin signaling. Neuropeptide $Y$ and POMC neurons in the ARC contain leptin receptor (lqbal et al 2001), and leptin inhibits the expression of NPY and stimulates the expression of POMC (Backholer et al 2010). In ruminants, NPY has a predominantly inhibitory effect on the release of GnRH/LH in the presence and absence of estradiol (McShane et al 1992, Gazal et al 1998, Ichimaru et al 2001). In contrast, the POMC-derived peptide, melanocyte-stimulating hormone alpha ( $\alpha \mathrm{MSH})$, appears to stimulate $\mathrm{GnRH}$ release because the melanocortin receptor agonist, melanotan II, increases the release of LH in sheep (Backholer et al 2009). The effects of NPY and $\alpha \mathrm{MSH}$ might occur, at least in part, through direct actions on $\mathrm{GnRH}$ neurons. In rats, projections containing NPY and POMC are in apposition to GnRH neurons (Leranth et al 1988, Li et al 1999), and in mice, both NPY and $\alpha \mathrm{MSH}$ affect GnRH neuronal depolarization frequency in a manner consistent with excitatory $(\alpha M S H)$ and inhibitory (NPY) effects (Roa \& Herbison 2012).

Neuropeptide $\mathrm{Y}$ and POMC neuronal projections to kisspeptin neurons may also have a functional relevance for the nutritional control of reproductive neuroendocrine function. Projections containing NPY are observed in apposition to kisspeptin neurons in sheep (Backholer et al 2010) and these projections may form synaptic inputs (Amstalden et al 2011). Projections containing POMC have also been observed in close proximity to kisspeptin neurons in sheep (Backholer et al 2010) and cattle (RC Cardoso, GL Williams \& M Amstalden, unpublished observations). In a study using anestrous ewes primed with progesterone, melanotan II stimulated KISS1 expression in the POA, but inhibited expression in the ARC (Backholer et al 2009). Projections containing kisspeptin are observed in proximity to NPY and POMC neurons (Backholer et al 2010), and the physiological relevance of these reciprocal projections have begun to be revealed. Intracerebroventricular injection of kisspeptin has been observed to enhance NPY and inhibit POMC expression in the ARC (Backholer et al 2010). In mice, kisspeptin increases excitation of POMC neurons and inhibit depolarization in NPY neurons (Fu et al 2010). Although central administration of kisspeptin has been observed to decrease food intake in mice (Stengel et al 2011), such an effect has not been observed in rats (Castellano et al 2005) or sheep (Clarke et al 2012). Therefore, a role for kisspeptin on the control of nutrient homeostasis and energy expenditure via NPY and POMC neurons, particularly during pubertal development, is still unclear.

\section{Functional programming of the kisspeptin neuronal network for timing the onset of puberty}

Hypothalamic pathways involved in the control of neuroendocrine functions are established during development; however, neuronal projections and connections among cells in the 
hypothalamus continue to develop postnatally (Coupé et al 2010). Steroid hormones and metabolic factors have a major impact on this process. By altering early postnatal nutrition in mice via manipulations of litter size, Caron et al (2012) observed that kisspeptin projections in adults are impacted by undernutrion during the infantile period. This effect may involve leptin signaling. An early postnatal elevation in circulating concentrations of leptin has been proposed to be a critical event programming neuroendocrine functions in mammals (reviewed by Bouret 2010). Regulation of gene expression in the hypothalamus and differential innervation of hypothalamic areas by NPY and POMC neurons are some of the apparent effects of leptin during the early postnatal period (Coupé et al 2010). The postnatal increase in leptin is largely associated with maternal nutrition during pregnancy (Coupé et al 2010, Long et al 2011) and early postnatal nutrition of the offspring (Ehhardt et al 2003). Overall, these observations indicate that neurons within the kisspeptin network are predisposed preand postnatally to programming by endocrine and metabolic factors.

To better understand the role of infantile and juvenile nutrition in the programming of neuroendocrine functions controlling the onset of puberty, we have conducted studies using an animal model developed by Gasser et al (2006) in which age at puberty is advanced in heifers fed high-concentrate diets to promote elevated body weight gain between 4 and 8 mo of age. In a study in which heifers were fed to gain body weight at high $(0.9 \mathrm{~kg} /$ day $)$ or low $(0.45 \mathrm{~kg} /$ day) rate from approximately 4 to 6.5 months of age, we observed an intricate regulation in the expression of genes in the ARC concurrent with increased circulating concentrations of leptin in high-gain heifers (Allen et al 2012). Genes detected to be differentially regulated in this study (Fig. 2) included those involved in the nutritional and metabolic control of feed intake (e.g., NPY and POMC). In addition, differential expression of genes involved in neuronal remodeling, axonal growth, synaptic vesicle transport and synaptic transmission is also observed and appears to be relevant for the nutritional programming of puberty. Using a similar nutritional model, we have investigated whether nutrition during the infantile and juvenile period influences kisspeptin, NPY and $\alpha \mathrm{MSH}$ projections in various regions of the hypothalamus and toward GnRH neurons. In juvenile heifers, high rate of body weight gain was associated with decreased expression of NPY (BRC Alves, GL Williams \& M Amstalden, unpublished observations) and increased expression of POMC in the ARC (RC Cardoso, GL Williams \& M Amstalden unpublished observations). Although, no clear differences in NPY innervation of kisspeptin neurons were observed, the proportion of kisspeptin neurons in close proximity to $\alpha \mathrm{MSH}$-containing fibers was increased in heifers gaining body weight at high rates. Decreased NPY innervation of GnRH neurons, particularly those located in the MBH, was also observed (BRC Alves, GL Williams \& M Amstalden, unpublished observations). In another study in which a nutritional regimen was used to promote differential body weight gain and adiposity in peripubertal ewe lambs, we observed that the proportion of $\mathrm{GnRH}$ neurons located in the $\mathrm{MBH}$ in close apposition with three or more kisspeptin varicosities was greater in ewe lambs growing at high rates (M Bedenbaugh \& M Amstalden, unpublished observations). However, at that stage of development, only a small number of GnRH neurons was observed to be in close proximity to kisspeptin fibers. Nevertheless, a complex interaction among kisspeptin, NPY and POMC neurons appears to exist and the function of this neuronal network may be regulated during infantile and juvenile development. Because reciprocal projections among kisspeptin, NPY and POMC neurons are evident, changes in the neuronal activity and connectivity within cells of this neuronal network is likely to regulate the output of downstream signals including GnRH secretory activity. 


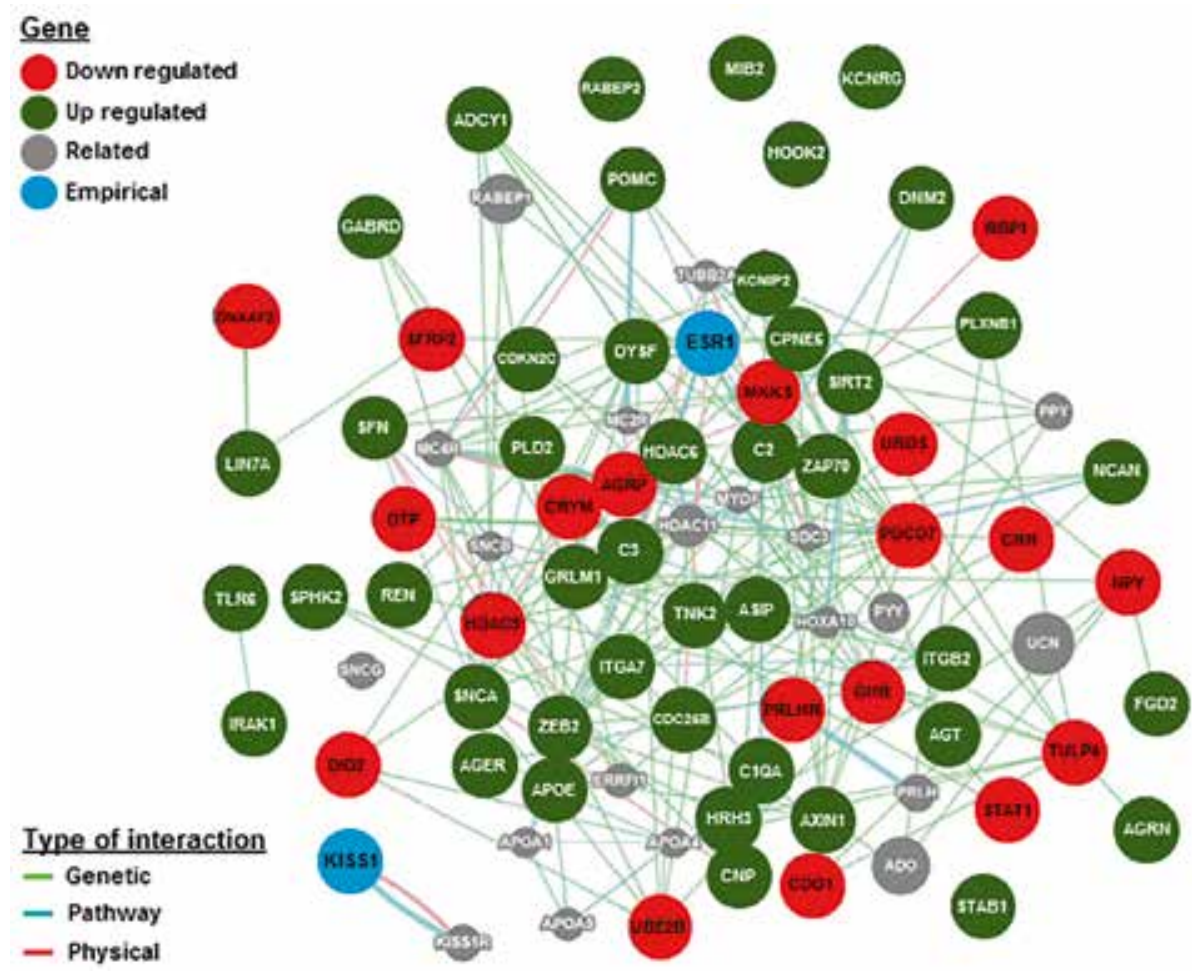

Fig. 2. Network of genes expressed in the arcuate nucleus of 6.5 month-old prepubertal heifers covering gene ontology (GO) terms for cell organization and morphogenesis, response to hormones, and cell metabolism. An increased rate of body weight gain during the juvenile period leads to increased (upregulated, green) and decreased (down-regulated, red) expression of genes involved in control of a number of biological functions including feeding behavior, response to nutrients and hormones, cell maturation, cell-cell communication, membrane organization, and synaptic transmission. Genes illustrated in gray represent genes highly-related to those observed to be differentially expressed. Genes illustrated in blue (empirical) have been observed to be critical for pubertal development in female mammals but were not observed to be differentially-expressed in the experiment by Allen et al (2011). ESR1 is highly interconnected to differentially-expressed genes, indicating a potentially central hierarchical role in the network. In contrast, interactions with KISS1 investigated in this network are minimal indicating a potential downstream role for kisspeptin in the pubertal activation of episodic release of GnRH later in development. [Network constructed using data reported previously (Allen et al 2011) and the GeneMANIA algorithm (http://www.genemania.org)].

Systems biology approach for understanding the role of kisspeptin in the control of pubertal development

Computational biology has become a valuable tool to investigate the genomic control of neuroendocrine systems timing the onset of puberty. A number of genes involved in regulating intracellular signaling and intercellular communications appear to be critical for the control of GnRH neuronal activity during pubertal development (Roth et al 2007). The approach of investigating the genetic networks involved in the control of pubertal maturation has identified highly-interactive components that are organized in a hierarchical order (reviewed by Lomniczie et al 2013a). The KISS1 gene is located downstream in this complex regulatory network (Heger 
et al 2007, Mastronardi et al 2006) and, although KISS1 is essential for normal reproductive function, it is regulated extensively by other genes in the hierarchical order. Thus, alterations in this genetic network are likely to influence the function of neurons within the pathways controlling GnRH neuronal activity.

A potential subordinate role for KISS1 in the genetic network controlling pubertal development in ruminant females is supported by various physiological studies. Although administration of kisspeptin stimulates ovulation/follicle luteinization in prepubertal lambs, regular estrous cyclicity is not established until a time coincident with saline-treated lambs (Redmond et al 2011a). This observation indicates that kisspeptin alone does not activate upstream components of the neuroendocrine pathway essential to sustain the pubertal pattern of $\mathrm{GnRH}$ secretory activity. Indeed, it appears that activation of KISS1 expression, particularly in the ARC, occurs as a later event in the maturation of the reproductive neuroendocrine axis and coincident with increased frequency of LH release (Redmond et al., 2011b). In addition, in models in which puberty is facilitated by increased rates of body weight gain during the infantile and juvenile periods, KISS1 does not emerge as a major differentially-regulated gene during earlier pubertal development in heifers (Fortes et al 2010, Allen et al 2012, Fortes et al 2012). This is confirmed by the limited association of KISS1 in the network of genes regulated by nutrition during juvenile development (Fig. 3). Nevertheless, KISS1 appears downstream to major regulatory genes critical for pubertal maturation. These include genes such as TTF1 (Mastronardi et al 2006) and PTTC1 (Heger et al 2007), both of which are known to regulate KISS1 expression activity (Mueller et al 2011). The RNA-binding protein encoded by LIN28

\section{Prepubertal}

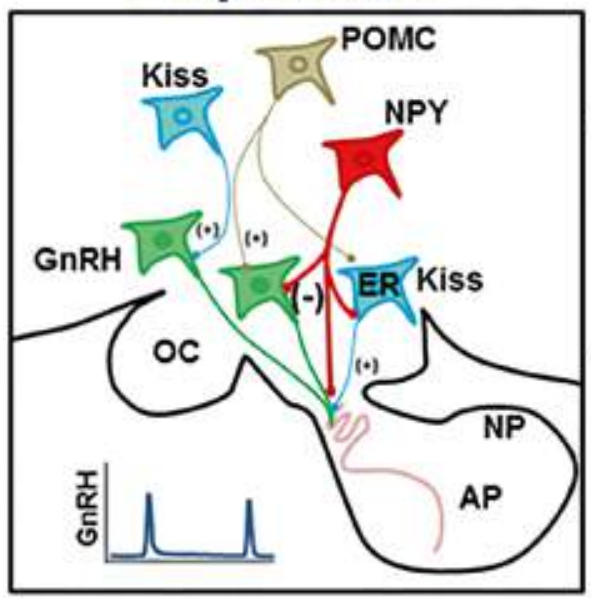

Pubertal

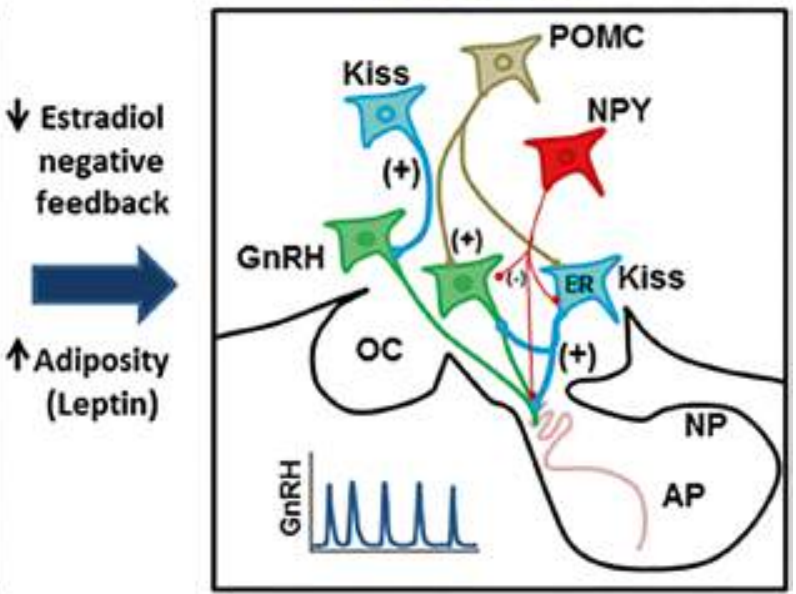

Fig. 3. Model depicting the involvement of kisspeptin neuronal networks in the pubertal activation of high-frequency $\mathrm{GnRH}$ release. A decrease in the sensitivity to estradiol negative feedback involves functional and structural changes in estrogen receptor (ER)-containing kisspeptin (Kiss) neurons. These changes include decreased ER signaling in kisspeptin neurons and increased kisspeptin contacts with GnRH neurons. Signals of nutritional status (e.g., leptin) act on neuropeptide Y (NPY) and proopiomelanocortin (POMC) neurons to regulate $\mathrm{GnRH}$ secretion. Plasticity in connections among cells in this neuronal networks and regulation of local release of transmitters and modulators facilitate the integration of endocrine and metabolic signals for the control of $\mathrm{GnRH}$ neuronal activity. The increase in excitatory stimuli and diminished inhibitory inputs to $\mathrm{GnRH}$ neurons result in increased frequency of episodic $\mathrm{GnRH}$ release and onset of puberty. 
regulates the transcription of regulatory factors that appear upstream to KISS1 (Lomniczi et al 2013a). Similarly to KISS1, LIN28 has also been observed to play a role in pubertal development in humans (Ong et al 2009), mice (Zhu et al 2010) and rats (Sangiao-Alvarellos et al 2013). In preliminary studies in cattle, we have observed evidence for changes in the methylation pattern of $L I N 28 B$ in heifers fed to gain body weight at high rates during the prepubertal period (BRC Alves, GL Williams \& M Amstalden, unpublished observations). Moreover, epigenetic changes in transcriptional regulators that affect KISS1 activity have been demonstrated (Lomniczi et al 2013b) and may contribute to the mechanisms by which kisspeptin neurons are involved in the control of pubertal development in mammals.

\section{Conclusions}

Activation of KISS1 expression appears to be critical for the pubertal onset of high-frequency release of $\mathrm{GnRH}$. Functional changes in the kisspeptin neuronal network may decode the changes in the sensitivity to estradiol negative feedback and integrate nutritional signals that time the onset of puberty. The control of a complex network of genes expressed in the hypothalamus underlies, at least in part, the molecular mechanisms controlling KISS1 expression. Additional studies characterizing the biological roles of these genes, and their relevance within each cellular component of the kisspeptin neuronal network, are essential for improving our understanding of mechanisms involved in the pubertal activation of $\mathrm{GnRH}$ secretion.

\section{Acknowledgements}

Authors would like to acknowledge the support of the USDA National Institute of Food and Agriculture through the Agriculture and Food Research Initiative Competitive Grant no. 200965203-05678 and the National Institutes of Health Grant R03HD064761-01.

\section{References}

Allen CC, Alves BR, Li X, Tedeschi LO, Zhou H, Paschal JC, Riggs PK, Braga-Neto UM, Keisler DH, Williams GL \& Amstalden M 2012 Gene expression in the arcuate nucleus of heifers is affected by controlled intake of highand low-concentrate diets. Journal of Animal Science $\mathbf{9 0}$ 2222-2232.

Amstalden M, Alves BR, Liu S, Cardoso RC \& Williams GL 2011 Neuroendocrine pathways mediating nutritional acceleration of puberty: insights from ruminant models. Frontiers in Endocrinology 2109.

Arreguin-Arevalo JA, Lents CA, Farmerie TA, Nett TM \& Clay CM. 2007 KiSS-1 peptide induces release of LH by a direct effect on the hypothalamus of ovariectomized ewes. Animal Reproduction Science 101 265-275.

Backholer K, Smith J \& Clarke IJ 2009 Melanocortins may stimulate reproduction by activating orexin neurons in the dorsomedial hypothalamus and kisspeptin neurons in the preoptic area of the ewe. Endocrinology 150 5488-5497.

Backholer K, Smith JT, Rao A, Pereira A, Iqbal J, Ogawa S, Li Q \& Clarke IJ 2010 Kisspeptin cells in the ewe brain respond to leptin and communicate with neuropeptide $\mathrm{Y}$ and proopiomelanocortin cells. Endocrinology 151 2233-2243.

Berardinelli JG, Dailey RA, Butcher RL \& Inskeep EK 1979
Source of progesterone prior to puberty in beef heifers. Journal of Animal Science 49 1276-1280.

Bouret SG 2010 Role of early hormonal and nutritional experiences in shaping feeding behavior and hypothalamic development. Journal of Nutrition 140 653-657.

Caraty A, Fabre-Nys C, Delaleu B, Locatelli A, Bruneau G, Karsch FJ \& Herbison A. 1998 Evidence that the mediobasal hypothalamus is the primary site of action of estradiol in inducing the preovulatory gonadotropin releasing hormone surge in the ewe. Endocrinology 139 1752-1760.

Caron E, Ciofi P, Prevot V \& Bouret SG 2012 Alteration in neonatal nutrition causes perturbations in hypothalamic neural circuits controlling reproductive function. Journal of Neuroscience 32 11486-11494.

Castellano JM, Navarro VM, Fernandez-Fernandez R, Nogueiras R, Tovar S, Roa J, Vazquez MJ, Vigo E, Casanueva FF, Aguilar E et al 2005 Changes in hypothalamic KiSS-1 system and restoration of pubertal activation of the reproductive axis by kisspeptin in undernutrition. Endocrinology 146 3917-3925.

Castellano JM, Navarro VM, Fernández-Fernández R, Roa J, Vigo E, Pineda R, Dieguez C, Aguilar E, Pinilla L \& Tena-Sempere M 2006 Expression of hypothalamic KiSS- 
1 system and rescue of defective gonadotropic responses by kisspeptin in streptozotocin-induced diabetic male rats. Diabetes 55 2602-2610.

Cheung CC, Thornton JE, Nurani SD, Clifton DK \& Steiner RA 2001 A reassessment of leptin's role in triggering the onset of puberty in the rat and mouse. Neuroendocrinology 74 12-21.

Clarke IJ, Smith JT, Henry BA, Oldfield BJ, Stefanidis A, Millar RP, Sari IP, Chng K, Fabre-Nys C, Caraty A et al 2012 Gonadotropin-inhibitory hormone is a hypothalamic peptide that provides a molecular switch between reproduction and feeding. Neuroendocrinology 95 305-316.

Clarkson J, Boon WC, Simpson ER \& Herbison AE 2009 Postnatal development of an estradiol-kisspeptin positive feedback mechanism implicated in puberty onset. Endocrinology 150 3214-3220.

Coupé B, Amarger V, Grit I, Benani A \& Parnet P 2010 Nutritional programming affects hypothalamic organization and early response to leptin. Endocrinology 151 702-713.

Day ML, Imakawa K, Garcia-Winder M, Zalesky DD, Schanbacher BD, Kittok RJ \& Kinder JE 1984 Endocrine mechanisms of puberty in heifers: estradiol negative feedback regulation of luteinizing hormone secretion. Biology of Reproduction 31 332-341.

Day ML, Imakawa K, Zalesky DD, Kittok RJ \& Kinder JE 1986 Effects of restriction of dietary energy intake during the prepubertal period on secretion of luteinizing hormone and responsiveness of the pituitary to luteinizing hormone-releasing hormone in heifers. Journal Animal Science 62 1641-1648.

Desroziers E, Mikkelsen JD, Duittoz A \& Franceschini I 2012 Kisspeptin-immunoreactivity changes in a sexand hypothalamic-region-specific manner across rat postnatal development. Journal of Neuroendocrinology 24 1154-1165.

Donato J Jr, Cravo RM, Frazão R, Gautron L, Scott MM, Lachey J, Castro IA, Margatho LO, Lee S, Lee C et al 2011 Leptin's effect on puberty in mice is relayed by the ventral premammillary nucleus and does not require signaling in Kiss1 neurons. Journal of Clinical Investigation 121 355-368.

Dorling AA, Todman MG, Korach KS \& Herbison AE 2003 Critical role for estrogen receptor alpha in negative feedback regulation of gonadotropin-releasing hormone mRNA expression in the female mouse. Neuroendocrinology 78 204-209.

Ebling FJP, Kushler RH \& Foster DL 1990 Pulsatile LH secretion during sexual maturation in the female sheep: photoperiodic regulation in the presence and absence of ovarian steroid feedback as determined in the same individual. Neuroendocrinology 52 229-237.

Ehrhardt RA, Greenwood PL, Bell AW \& Boisclair YR 2003 Plasma leptin is regulated predominantly by nutrition in preruminant lambs. Journal of Nutrition 133 4196-4201.

Fortes MR, Reverter A, Zhang Y, Collis E, Nagaraj SH, Jonsson NN, Prayaga KC, Barris W \& Hawken RJ 2010 Association weight matrix for the genetic dissection of puberty in beef cattle. Proceedings of the National Academy of Science USA 107 13642-1347.
Fortes MR, Snelling WM, Reverter A, Nagaraj SH, Lehnert SA, Hawken RJ, DeAtley KL, Peters SO, Silver GA, Rincon G et al 2012 Gene network analyses of first service conception in Brangus heifers: use of genome and trait associations, hypothalamic-transcriptome information, and transcription factors. Journal of Animal Science $\mathbf{9 0}$ 2894-2906.

Foster DL \& Jackson LM 2006 Puberty in the sheep. In Knobil and Neill's Physiology of Reproduction, pp 2127-2176. Ed JD Neill. New York/Oxford, UK: Elsevier/Academic.

Foster DL \& Olster DH 1985 Effect of restricted nutrition on puberty in the lamb: patterns of tonic luteinizing hormone (LH) secretion and competency of the LH surge system. Endocrinology 116 375-381.

Franceschini I, Lomet D, Cateau M, Delsol G, Tillet Y \& Caraty A 2006 Kisspeptin immunoreactive cells of the ovine preoptic area and arcuate nucleus co-express estrogen receptor alpha. Neuroscience Letters $\mathbf{4 0 1}$ 225-230.

Fu LY \& van den Pol AN 2010 Kisspeptin directly excites anorexigenic proopiomelanocortin neurons but inhibits orexigenic neuropeptide $\mathrm{Y}$ cells by an indirect synaptic mechanism. Journal of Neuroscience 30 10205-10219.

Gasser CL, Bridges GA, Mussard ML, Grum DE, Kinder JE \& Day ML 2006 Induction of precocious puberty in heifers III: hastened reduction of estradiol negative feedback on secretion of luteinizing hormone. Journal of Animal Science 84 2050-2056.

Gazal OS, Leshin LS, Stanko RL, Thomas MG, Keisler DH, Anderson LL \& Williams GL. 1998 Gonadotropinreleasing hormone secretion into third-ventricle cerebrospinal fluid of cattle: correspondence with the tonic and surge release of luteinizing hormone and its tonic inhibition by suckling and neuropeptide Y. Biology of Reproduction 59 676-683.

Goodman RL, Lehman MN, Smith JT, Coolen LM, de Oliveira CV, Jafarzadehshirazi MR, Pereira A, Iqbal J, Caraty A, Ciofi P \& Clarke IJ 2007 Kisspeptin neurons in the arcuate nucleus of the ewe express both dynorphin A and neurokinin B. Endocrinology 148 5752-5760.

Han SK, Gottsch ML, Lee KJ, Popa SM, Smith JT, Jakawich SK, Clifton DK, Steiner RA \& Herbison AE 2005 Activation of gonadotropin-releasing hormone neurons by kisspeptin as a neuroendocrine switch for the onset of puberty. The Journal of Neuroscience 25 11349-11356.

Heger S, Mastronardi C, Dissen GA, Lomniczi A, Cabrera R, Roth CL, Jung H, Galimi F, Sippell W \& Ojeda SR 2007 Enhanced at puberty 1 (EAP1) is a new transcriptional regulator of the female neuroendocrine reproductive axis. Journal of Clinical Investigation 117 2145-2154.

Hoffman GE, Le WW, Franceschini I, Caraty A \& Advis JP 2011 Expression of fos and in vivo median eminence release of $\mathrm{LHRH}$ identifies an active role for preoptic area kisspeptin neurons in synchronized surges of $\mathrm{LH}$ and LHRH in the ewe. Endocrinology 152 214-222.

I'Anson H, Manning JM, Herbosa CG, Pelt J, Friedman CR, Wood RI, Bucholtz DC \& Foster DL 2000 Central inhibition of gonadotropin-releasing hormone secretion in the growth-restricted hypogonadotropic female sheep. Endocrinology 141 520-527.

Ichimaru T, Mori Y \& Okamura H 2001 A possible role of 
neuropeptide $\mathrm{Y}$ as a mediator of undernutrition to the hypothalamic gonadotropin-releasing hormone pulse generator in goats. Endocrinology 142 2489-2498.

Iqbal J, Pompolo S, Murakami T, Grouzmann E, Sakurai T, Meister B \& Clarke IJ 2001 Immunohistochemical characterization of localization of long-form leptin receptor $(\mathrm{OB}-\mathrm{Rb})$ in neurochemically defined cells in the ovine hypothalamus. Brain Research 920 55-64.

Kadokawa H, Matsui M, Hayashi K, Matsunaga N, Kawashima C, Shimizu T, Kida K \& Miyamoto A 2008 Peripheral administration of kisspeptin-10 increases plasma concentrations of $\mathrm{GH}$ as well as $\mathrm{LH}$ in prepubertal Holstein heifers. Journal of Endocrinology 196 331-334.

Kotani M, Detheux M, Vandenbogaerde A, Communi D, Vanderwinden JM, Le Poul E, Brézillon S, Tyldesley R, Suarez-Huerta N, Vandeput F et al 2001 The metastasis suppressor gene KiSS-1 encodes kisspeptins, the natural ligands of the orphan G protein-coupled receptor GPR54. Journal of Biological Chemistry 276 34631-3436.

Lehman MN \& Karsch FJ 1993 Do gonadotropin-releasing hormone, tyrosine hydroxylase-, and beta-endorphinimmunoreactive neurons contain estrogen receptors? A double-label immunocytochemical study in the Suffolk ewe. Endocrinology 133 887-895.

Leranth C, MacLusky NJ, Shanabrough M \& Naftolin F 1988 Immunohistochemical evidence for synaptic connections between pro-opiomelanocortin-immunoreactive axons and $\mathrm{LH}-\mathrm{RH}$ neurons in the preoptic area of the rat. Brain Research 449 167-176.

Li C, Chen P \& Smith MS 1999 Morphological evidence for direct interaction between arcuate nucleus neuropeptide Y (NPY) neurons and gonadotropin-releasing hormone neurons and the possible involvement of NPY Y1 receptors. Endocrinology 140 5382-5390.

Li XF, Kinsey-Jones JS, Cheng Y, Knox AM, Lin Y, Petrou NA, Roseweir A, Lightman SL, Milligan SR, Millar RP \& O'Byrne KT 2009 Kisspeptin signalling in the hypothalamic arcuate nucleus regulates $\mathrm{GnRH}$ pulse generator frequency in the rat. PLoS One 4 e8334.

Lomniczi A, Wright H, Castellano JM, Sonmez K \& Ojeda SR 2013a A system biology approach to identify regulatory pathways underlying the neuroendocrine control of female puberty in rats and nonhuman primates. Hormonal Behavior 64 175-186.

Lomniczi A, Loche A, Castellano JM, Ronnekleiv OK, Bosch M, Kaidar G, Knoll JG, Wright H, Pfeifer GP \& Ojeda SR. 2013b Epigenetic control of female puberty. Nature Neuroscience 16 281-289.

Long NM, Ford SP \& Nathanielsz PW 2011 Maternal obesity eliminates the neonatal lamb plasma leptin peak. Journal of Physiology 589 1455-1462.

Maciel MN, Zieba DA, Amstalden M, Keisler DH, Neves JP \& Williams GL 2004 Chronic administration of recombinant ovine leptin in growing beef heifers: effects on secretion of $\mathrm{LH}$, metabolic hormones, and timing of puberty. Journal of Animal Science 82 2930-2936.

Mastronardi C, Smiley GG, Raber J, Kusakabe T, Kawaguchi A, Matagne V, Dietzel A, Heger S, Mungenast AE, Cabrera R et al 2006 Deletion of the Ttf1 gene in differentiated neurons disrupts female reproduction without impairing basal ganglia function. Journal of
Neuroscience 26 13167-13179.

Mayer C \& Boehm U 2011 Female reproductive maturation in the absence of kisspeptin/GPR54 signaling. Nature Neuroscience 14 704-710.

Mayer C, Acosta-Martinez M, Dubois SL, Wolfe A, Radovick S, Boehm U \& Levine JE 2010 Timing and completion of puberty in female mice depend on estrogen receptor alpha-signaling in kisspeptin neurons. Proceedings of the National Academy of Science USA 107 22693-22698.

McShane TM, May T, Miner JL \& Keisler DH 1992 Central actions of neuropeptide-Y may provide a neuromodulatory link between nutrition and reproduction. Biology of Reproduction 46 1151-1157.

Merkley CM, Porter KL, Coolen LM, Hileman SM, Billings HJ, Drews S, Goodman RL \& Lehman MN 2012 KNDy (Kisspeptin/Neurokinin B/Dynorphin) neurons are activated during both pulsatile and surge secretion of $\mathrm{LH}$ in the ewe. Endocrinology 153 5406-5414.

Messager S, Chatzidaki EE, Ma D, Hendrick AG, Zahn D, Dixon J, Thresher RR, Malinge I, Lomet D, Carlton MBL et al 2005 Kisspeptin directly stimulates gonadotropinreleasing hormone release via $\mathrm{G}$ protein-coupled receptor 54. Proceedings of the National Academy of Sciences USA 102 1761-1766.

Mittelman-Smith MA, Williams H, Krajewski-Hall SJ, Lai J, Ciofi P, McMullen NT \& Rance NE 2012 Arcuate kisspeptin/neurokinin B/dynorphin (KNDy) neurons mediate the estrogen suppression of gonadotropin secretion and body weight. Endocrinology 153 28002812.

Mueller JK, Dietzel A, Lomniczi A, Loche A, Tefs K, Kiess W, Danne T, Ojeda SR \& Heger S 2011 Transcriptional regulation of the human KiSS1 gene. Molecular and Cellular Endocrinology 342 8-19.

Navarro VM, Fernández-Fernández R, Castellano JM, Roa J, Mayen A, Barreiro ML, Gaytan F, Aguilar E, Pinilla L, Dieguez C \& Tena-Sempere M 2004 Advanced vaginal opening and precocious activation of the reproductive axis by KiSS-1 peptide, the endogenous ligand of GPR54. Journal of Physiology 561 379-386.

Nestor CC, Briscoe AM, Davis SM, Valent M, Goodman RL \& Hileman SM 2012 Evidence of a role for kisspeptin and neurokinin B in puberty of female sheep. Endocrinology 153 2756-2765.

Ohkura S, Uenoyama Y, Yamada S, Homma T, Takase K, Inoue N, Maeda K \& Tsukamura H 2009 Physiological role of metastin/kisspeptin in regulating gonadotropinreleasing hormone $(\mathrm{GnRH})$ secretion in female rats. Peptides 30 49-56.

Ong KK, Elks CE, Li S, Zhao JH, Luan J, Andersen LB, Bingham SA, Brage S, Smith GD, Ekelund U et al 2009 Genetic variation in LIN28B is associated with the timing of puberty. Nature Genetics 41 729-733.

Pineda R, Garcia-Galiano D, Roseweir A, Romero M, Sanchez-Garrido MA, Ruiz-Pino F, Morgan K, Pinilla L, Millar RP \& Tena-Sempere M 2010 Critical roles of kisspeptins in female puberty and preovulatory gonadotropin surges as revealed by a novel antagonist. Endocrinology 151 722-730.

Quennell JH, Mulligan AC, Tups A, Liu X, Phipps SJ, Kemp CJ, Herbison AE, Grattan DR \& Anderson GM 
2009 Leptin indirectly regulates gonadotropin-releasing hormone neuronal function. Endocrinology 150 28052812.

Quennell JH, Howell CS, Roa J, Augustine RA, Grattan DR \& Anderson GM 2011 Leptin deficiency and diet-induced obesity reduce hypothalamic kisspeptin expression in mice. Endocrinology 152 1541-1550.

Redmond JS, Macedo GG, Velez IC, Caraty A, Williams GL \& Amstalden M 2011a Kisspeptin activates the hypothalamic-adenohypophyseal-gonadal axis in prepubertal ewe lambs. Reproduction 141 541-548.

Redmond JS, Baez-Sandoval GM, Spell KM, Spencer TE, Lents CA, Williams GL \& Amstalden M 2011b Developmental changes in hypothalamic Kiss1 expression during activation of the pulsatile release of luteinising hormone in maturing ewe lambs. Journal of Neuroendocrinology 23 815-822.

Roa J \& Herbison AE 2012 Direct regulation of GnRH neuron excitability by arcuate nucleus POMC and NPY neuron neuropeptides in female mice. Endocrinology 153 5587-5599.

Roth CL, Mastronardi C, Lomniczi A, Wright H, Cabrera $R$, Mungenast AE, Heger S, Jung $H$, Dubay $C$ \& Ojeda SR 2007 Expression of a tumor-related gene network increases in the mammalian hypothalamus at the time of female puberty. Endocrinology 148 5147-5161.

de Roux N, Genin E, Carel JC, Matsuda F, Chaussain JL \& Milgrom E 2003 Hypogonadotropic hypogonadism due to loss of function of the KiSS1-derived peptide receptor GPR54. Proceedings of the National Academy of Science USA 100 10972-10976.

Sangiao-Alvarellos S, Manfredi-Lozano M, Ruiz-Pino F, Navarro VM, Sánchez-Garrido MA, Leon S, Dieguez C, Cordido F, Matagne V, Dissen GA et al 2013 Changes in hypothalamic expression of the Lin28/let-7 system and related microRNAs during postnatal maturation and after experimental manipulations of puberty. Endocrinology 154 942-955.

Satoh N, Ogawa Y, Katsuura G, Hayase M, Tsuji T, Imagawa K, Yoshimasa Y, Nishi S, Hosoda K \& Nakao K 1997 The arcuate nucleus as a primary site of satiety effect of leptin in rats. Neuroscience Letters 224 149-152.

Seminara SB, Messager S, Chatzidaki EE, Thresher RR, Acierno JS Jr, Shagoury JK, Bo-Abbas Y, Kuohung W, Schwinof KM, Hendrick AG et al 2003 The GPR54 gene as a regulator of puberty. New England Journal of Medicine 349 1614-1627.

Sinchak K \& Wagner EJ 2012 Estradiol signaling in the regulation of reproduction and energy balance. Frontiers in Neuroendocrinology 33 342-363.

Smith JT, Cunningham MJ, Rissman EF, Clifton DK \& Steiner RA 2005 Regulation of Kiss1 gene expression in the brain of the female mouse. Endocrinology 146 3686-3692.

Smith JT, Acohido BV, Clifton DK\& Steiner RA 2006 KiSS-1 neurones are direct targets for leptin in the ob/ob mouse. Journal of Neuroendocrinology 18 298-303.

Smith JT, Clay CM, Caraty A \& Clarke IJ 2007 KiSS1 messenger ribonucleic acid expression in the hypothalamus of the ewe is regulated by sex steroids and season. Endocrinology 148 1150-1157.
Smith JT, Coolen LM, Kriegsfeld LJ, Sari IP, Jaafarzadehshirazi MR, Maltby M, Bateman K, Goodman RL, Tilbrook AJ, Ubuka T et al 2008a Variation in kisspeptin and RFamide-related peptide (RFRP) expression and terminal connections to gonadotropin-releasing hormone neurons in the brain: a novel medium for seasonal breeding in the sheep. Endocrinology 149 5770-5782.

Smith JT, Rao A, Pereira A, Caraty A, Millar RP \& Clarke IJ 2008 b Kisspeptin is present in ovine hypophysial portal blood but does not increase during the preovulatory luteinizing hormone surge: evidence that gonadotropes are not direct targets of kisspeptin in vivo. Endocrinology 149 1951-1959.

Smith JT, Li Q, Pereira A \& Clarke IJ 2009 Kisspeptin neurons in the ovine arcuate nucleus and preoptic area are involved in the preovulatory luteinizing hormone surge. Endocrinology 150 5530-5538.

Smith JT, Li Q, Yap KS, Shahab M, Roseweir AK, Millar RP \& Clarke IJ 2011 Kisspeptin is essential for the full preovulatory LH surge and stimulates $\mathrm{GnRH}$ release from the isolated ovine median eminence. Endocrinology 152 1001-1012.

Stengel A, Wang L, Goebel-Stengel M \& Taché Y 2011 Centrally injected kisspeptin reduces food intake by increasing meal intervals in mice. Neuroreport 22 253257.

Suzuki S, Kadokawa H \& Hashizume T 2008 Direct kisspeptin-10 stimulation on luteinizing hormone secretion from bovine and porcine anterior pituitary cells. Animal Reproduction Science 103 360-365.

Takase K, Uenoyama Y, Inoue N, Matsui H, Yamada S, Shimizu M, Homma T, Tomikawa J, Kanda S, Matsumoto $\mathbf{H}$ et al 2009 Possible role of oestrogen in pubertal increase of Kiss1/kisspeptin expression in discrete hypothalamic areas of female rats. Journal of Neuroendocrinology 21 527-537.

Tomikawa J, Homma T, Tajima S, Shibata T, Inamoto Y, Takase K, Inoue N, Ohkura S, Uenoyama Y, Maeda K \& Tsukamura H 2010 Molecular characterization and estrogen regulation of hypothalamic KISS1 gene in the pig. Biology of Reproduction 82 313-319.

Wakabayashi Y, Nakada T, Murata K, Ohkura S, Mogi K, Navarro VM, Clifton DK, Mori Y, Tsukamura H, Maeda K et al 2010 Neurokinin B and dynorphin A in kisspeptin neurons of the arcuate nucleus participate in generation of periodic oscillation of neural activity driving pulsatile gonadotropin-releasing hormone secretion in the goat. Journal of Neuroscience 30 3124-3132.

Yeo SH \& Herbison AE 2011 Projections of arcuate nucleus and rostral periventricular kisspeptin neurons in the adult female mouse brain. Endocrinology 152 2387-2399.

Zhu H, Shah S, Shyh-Chang N, Shinoda G, Einhorn WS, Viswanathan SR, Takeuchi A, Grasemann C, Rinn JL, Lopez MF et al 2010 Lin28a transgenic mice manifest size and puberty phenotypes identified in human genetic association studies. Nature Genetics 42 626-630.

Zieba DA, Amstalden M, Morton S, Maciel MN, Keisler DH \& Williams GL 2004 Regulatory roles of leptin at the hypothalamic-hypophyseal axis before and after sexual maturation in cattle. Biology of Reproduction 71 804-812. 